\title{
MANAGEMENT IMPERATIVES OF CORRUPTION AND GOVERNANCE FAILURES IN NIGERIA
}

John N.N. Ugoani, PhD College of Management and Social Sciences, Nigeria Email: drjohnugoani@yahoo.com

Submission: 04/10/2016

Revision: 30/12/2016 Accept: 22/07/2017

\section{ABSTRACT}

Mismanagement and corruption negatively affect the society and lead to poor service delivery, poverty and governance failures. Nigeria has a long history of deceitful leadership and governance deeply rooted in corruption. This entrenchment of corruption has made it difficult for the nation to divorce itself from the problems of governance failures. Some public officers dish out public funds with reckless abandon, in the manner that debases democracy and the principles of good governance. Despite President Obasanjo's personal commitment to fight corruption during his tenure the epidemic remains in Nigeria. In Nigeria about 70 percent of past administrations are perceived as corrupt and about 70 percent of the citizens are poor. The government need to muster the political will to recover all stolen public funds because no governor, no deputy governor, no president, no vice president no chairman, no vice chairman is immune from criminal investigation, and section 308 of the constitution might not mean so. Exploratory research design was used for the study. Data were analyzed through descriptive statistical method, and it was found that corruption contributes to governance failures in Nigeria.

Keywords: Mismanagement, Corruption, Plutocrats, Paupers, Middle class, Militancy, Poverty, Governance, Leadership, Doctrine of necessity, Yam and goat mentality. 


\section{INTRODUCTION}

Mismanagement is another name for describing corruption since it connotes managing resources incompetently, fraudulently and dishonestly. Corruption which relates to the abuse of public office for personal benefits is as old as mankind. It often incastrates governments, render them impotent, and ultimately results in governance failures.

Governance is basically, the exercise of authority held in trust, for the benefit of the people in society. However, Nigeria's history is almost synonymous with the history of corruption and governance failures, starting from the colonial days to the present time.

According to Semenitari $\left(2005^{a}\right.$ ) some Nigerians believe that among the problems of Nigeria include its history of deceitful leadership that has existed for long, in which case, the people no longer trust their leaders. Smith $\left(2005^{\mathrm{a}}\right)$ summaries the political intrigues and shenanigans that took place under the supervision of the London Colonial Office as "the last great treacherous act of the British Raj".

According to him, what took place in the name of constitutional conferences, elections, and population census was nothing to the British but a way to prosecute one of their numerous wars. He posits that "even though the British knew his other name was Mr. Corruption, they saw no evil in him for he was their puppet. And Mr. corruption championed the deal that ensured a two-party federal coalition".

He states that from his experience with Okotie-Eboh, it seemed that the British government wanted to hand over power to a corrupt group of politicians. Suggesting that, perhaps, corruption was seen as the speedy way to create a conservative middle class which would be sound, stable and most important, anti-communist (SMITH ${ }^{\mathrm{b}}$, 2005; SMITH, 2005c; SEMENITARI, 2005 ${ }^{\mathrm{b}}$ ).

By 1960, corruption has become entrenched in Nigeria. The number one problem identified by the military coup by the majors, for seizing political power in January, 1966, was corruption. According to Agwunobi (2005) the military in January 1966 saw bribery, and corruption, nepotism, tribalism, rabid regionalism and political antagonism as responsible for governance failures. 
INDEPENDENT JOURNAL OF MANAGEMENT \& PRODUCTION (IJM\&P)

http://www.ijmp.jor.br

v. 9, n. 1, January - March 2018

ISSN: 2236-269X

DOI: 10.14807/ijmp.v9i1.547

It identified the political profiteers, the "men and women in high and low places that took bribes and demanded ten percent, those that kept the country divided so that they could remain in office as ministers and VIPs of waste". Even though the Balewa regime was reactionary and totally corrupt, considerable efforts were put into constructing and backing the awful regime by the British.

Although the January 1966 military coup was bloody, it destroyed the totally discredited First Republic as Nigeria never had been the model democracy that the British claimed to have left behind. Moreover, the blatant corruption, election rigging and thuggery in the years from 1960 to 1966 did not start only when the British departed. They were instigated, condoned, tolerated and covered up by the British before Independence.

By 1966, the growing disillusion with the Balewa government, which was common among civil servants, teachers and academics, had spread to the Army, and quickly led to the bloody coup (TELL MAGAZINE, 2005). However, by the early 1970s the military government started exhibiting signs of corruption and inefficiency in governance, and the first reason for the overthrow of the military government of Gowon by Mohammed in 1975 was bad government.

The Mohammed government then put through a massive purge of a perceived powerful and highly corrupt public/civil service in 1975 (Agwunobi, 2005). However, according to Williams (1981), it was the military that put Nigeria into a Civil War, and was itself unstable to the extent that two military heads of state were assassinated and one deposed. He posits that even though the January 1966 military coup was not smooth, it was nevertheless widely welcomed by Nigerians, who were completely tired of the gangaterism, corruption and oppression of politicians' rule.

After a long military rule (1966-1979) the military surrendered political power to civilians in 1979. According to Williams (1981) the Shagari administration inherited a weak bureaucracy at all levels of administration, and public services strained by the expansion and the demands of an expanding economy, to which oil revenues gave immense strength, and also producing serious inflation. The Second Republic was shortly over-powered by corruption.

The politicians started to demand more than ten percent on government contracts, there was a bazaar of oil deals, payments for contracts not executed, 
INDEPENDENT JOURNAL OF MANAGEMENT \& PRODUCTION (IJM\&P)

http://www.ijmp.jor.br

v. 9, n. 1, January - March 2018

ISSN: 2236-269X

DOI: 10.14807/ijmp.v9i1.547

among others. According to Agwunobi (2005) "while all these went on, salaries of civil servants and teachers remained unpaid, hospitals remained without drugs, schools without textbooks, and there was a situation of uneven development, reflecting an uneven response to socio-economic change by government".

This bad governance posture accelerated the military coup in the wee hours of 1983 that was quickly justified on the basis of massive corruption in public life. The military could not easily kill corruption, but also struggled with it until 1999, when it again surrendered power to civilians.

The political party in government from 1999, even after singing anti-corruption songs aloud, establishing anti-corruption agencies, watched corruption to flow like river Niger, until it was itself washed away by corruption itself in 2015. With corruption issues such as the corruption and deceit behind the Lagos-Kano rail line project, among others, it is generally believed that past mismanagement destroyed the Nigerian economy (AKINREMI, 2015, ADEYEMI, 2015).

The arms deal has added another dimension to the corruption saga in Nigeria. Right at the presidency, contracts worth billions of naira were given out without due process and minimal documentation (Alli, 2015). Revelations about the use of public funds for political campaigns is a dangerous dimension of the impunity of corruption, against International Best Practices (US CORRUPT PRACTICES ACT, 1925).

Even though the military could not wipe out corruption in governance in Nigeria, it felt a political obligation to challenge the promotion of corruption in society. And again, according to Elaigwu (1985) no nation's armed forces can remain apart from politics, since politics is concerned with the distribution of values and power within a society (MAZRUI, 1973).

For Nigeria to achieve sustainable development, corruption must be reduced to the bearest minimum, and this requires a comprehensive framework that hinges on solid political will. For example, according to Akintayo (2016) Political will is a key ingredient in the transformation effort in Singapore's corruption infested past, as it formed it's all important sub-structure, upon which all the super-structures of anticorruption work nest. It provides the soil and the nutrient which allows the seeds of anticorruption work to germinate and grow. 
INDEPENDENT JOURNAL OF MANAGEMENT \& PRODUCTION (IJM\&P)

http://www.ijmp.jor.br

v. 9, n. 1, January - March 2018

ISSN: 2236-269X

DOI: 10.14807/ijmp.v9i1.547

According to Obasanjo (2016): Today corruption drains billions of dollars from our economy that cannot afford to lose even a million dollars. It seems we are just beginning the fight, until recently; it seems corruption had returned with a vengeance, taking a seat at the very heart of government. This statement reinforces the serious status of corruption in Nigeria governance structure. It is believed in high and low places that corruption is wealthy, powerful, influential and practically in all institutions, including religious institutions in Nigeria (OSINBAJO, 2017).

\subsection{Statement of the Problem}

Whether civilian or military government, corruption has been a major cause of governance failures in Nigeria. There are many faces and meanings of corruption that have continued to undermine the process of governance in Nigeria. In broad terms, a distinction can be made between governmental and private corruption.

The former being the one that directly involves government officials, ministries, departments and agencies, (MDAs) and jeopardizes good governance, while the latter is involved with corrupt practices in corporations, and others like the Halliburton multimillion dollar scam (DANIEL, 2016).

Public corruption could therefore be related to such ones as the billion dollars arms scandal in Nigeria. This was money recovered from a previous corrupt government and to be used to fight terrorism, but was instead shared by government officials, politicians, agents, touts, military commanders, militant commanders, and sundry others.

Tunji (2016) estimates that as at 2012, Nigeria had lost over $\$ 400$ billion to corruption since 1960. Corruption brought about the 1966 military coup. The 1983 Coup was justified on the basis of attempts to fight corruption in all its ramifications, but could not even with the so-called draconian Decrees.

The leaders of the 1985 military coup promised to clear the mess of all previous administrations and restore the country to the paths of bliss, with the introduction of jaw-breaking programmes like: The Directorate of Food, Roads and Rural Infrastructure (DFRRI), the Mass Mobilization for Reliance, Social Justice and Economic Recovery (MAMSER), Better Life for Rural Women, the Natural Directorate of Employment (NDE) among others. Out of the whole, only the NDE is 
INDEPENDENT JOURNAL OF MANAGEMENT \& PRODUCTION (IJM\&P)

http://www.ijmp.jor.br

v. 9, n. 1, January - March 2018

ISSN: 2236-269X

DOI: 10.14807/ijmp.v9i1.547

struggling to maintain its signpost today; the rest have been washed away by corruption.

Besides the allegations of missing \$12billion Gulf Oil money during the currency of the Babangida regime, there were allegations that those DFRRI, MAMSER, among others were conduit for siphoning public money from the treasury into private foreign accounts. Subsequent military regime of Abacha was neck deep in mismanagement and corruption, putting billions of dollars in far away countries, like the UK, USA, Germany, among others.

The succeeding civilian government was dinning and winning with Mr. Corruption for 16 years. At a time, it was thought that corruption had become institutionalized and a way of life, as was the case in Sierra Leone, and even racing to surpass it. According to Kpundeh (1999) under Presidents Stevens, Momoh, and Strasser, there was lack of political will to systematically fight corruption.

He posits that Momoh was responsible for a group that was drenched in sectionalism, tribalism, favouritism, nepotism, in-competence, ineptitude, treachery, indolence, winning, dinning and womanizing, which inflicted the severest mismanagement on the affairs of that country (UGOANI, 2016).

Because of the high levels of mismanagement and corruption in Nigeria, many Nigerians believe that the war against them must not be left to the government alone to fight, bearing in mind the fact that corruption is everywhere in Nigeria. According to Omonijo, et al (2005) President Obasanjo's view suggesting that a purported 3rd term opportunity could provide a framework for the economic plan of his administration, and how the policies could bring about radical changes on the six planks of the economic framework before 2030, did not go down well with many politicians, and almost overheated the polity.

That also caused a serious erosion of confidence on the Obasanjo administration, despite its anticorruption posture. Na Abba (2006) thought that despite the efforts of the Obasanjo administration corruption was everywhere in Nigeria. In a book review Sowemimo (2006) reports that Nigerians need to retrace their steps from corruption and embrace hard work, dedication and the will to collectively move the nation away from the unenviable derogatory appellation as the third most corrupt nation on planet earth, to join the big league of saints. Some state 
INDEPENDENT JOURNAL OF MANAGEMENT \& PRODUCTION (IJM\&P)

http://www.ijmp.jor.br

v. 9, n. 1, January - March 2018

ISSN: 2236-269X

DOI: 10.14807/ijmp.v9i1.547

governments are known for abandoned projects and even paying for jobs not executed.

For example, Ero (2005) reports that Edo State legislature found out that the state government paid N14billion for poorly executed road works, mostly without contract agreements. Eriye (2011) laments that Nigerians have fought sundry wars, the bloody Civil War, the bloodless but short-lived War Against Indiscipline (WAI) and some others.

But in spite of our apparent warlike ways, we do not have an appetite for a war against corruption. In a country that produces oil, and where there is always oil scarcity, business people, politicians, and oil marketers are drenched in corruption in the oil and gas sector (OGS). Alli (2012) states that 20 marketers arraigned for oil subsidy scam had lobbied for the invocation of plea bargaining with a strong commitment to refund excess subsidy cash involving about N400billion paid to them (ANUMIHEB, 2016).

Against all the mess, under the presidency of Yar'Adua, Abubakar (2007) reports that the President of Nigeria had said and decreed that people should have a say on who leads them and until the people cast their votes, they should expect accountability. This lone voice was quickly over taken by corruption, and the corruption bazaar continued unabated.

According to Media Trust Ltd (2005) corruption is the problem with Nigeria. Poor quality of service delivery is common across public sector institutions in Nigeria, suggesting a lack of good management in the governance architecture. There is need for good management in governance because governance could best operate when there is less corruption and when there is consistency between resources and establishment of good governance and management structures which have transparency and higher degree of accountability.

As MDAs and other institutions remain vulnerable to political corruption and opportunism in Nigeria, what is needed is a high dose of political will to prosecute governance reforms and institute competent management for the reengineering of public affairs for the benefit of the greater majority. The present government is spending a great deal of time chasing about US\$150bn of public funds purportedly mismanaged by the instrumentality of corruption and put away in unknown places 
(Laccino, 2015) Today, corruption and mismanagement in the public sector continue to rape the nation of necessary funds for sustainable development.

According to Anumihe (2016a) the Federal Government in 2013 lost over US\$518 million to oil swap and Offshore Processing Arrangements (OPAs) due to inefficiencies by the Nigerian National Petroleum Corporation (NNPC) and its subsidiaries. Corruption has done great damage to the global economy and the attainment of the Sustainable Development Goals (SDGs) target in 2030 requires a united action against it.

For example, according to Kerry (2016) the global cost of corruption is about US\$2.6trillion per annum. Corruption has been the bane of poor governance that has resulted to the impeachment of two governors in the country's recent political history. For example, Alamieyeseigha was impeached after he was accused and found guilty of corrupt acquisition of shares in some companies, a refinery in Ecuador, and properties in Lagos, Abuja, Port Harcourt, London, among other sundry criminal offences (MANUAKA, 2005).

The heavy evidence of corruption, its negative effect on governance, as well as the consequences of poverty and unemployment make a study of this nature very urgent, at least now that no earlier study known to the researcher had done so in details with respect to Nigeria (NZENWA, 2000, NWIZU, 2002).

\subsection{Objective of the Study}

The study was designed to explore the roots of corruption and governance failures in Nigeria.

\subsection{Significance of the Study}

The study will help students, academics, governments, researchers and others interested in public sector management understand the role of corruption with regard to mismanagement and governance failures in Nigeria.

\subsection{Research Questions}

To achieve the objective of the study, three research questions were formulated.

a) Is there any evidence of mismanagement in Nigeria's public sector? 
b) Is there any evidence of corruption among Nigerian leaders?

c) Does corruption influence governance failures in Nigeria?

\subsection{Restatement of Research Questions}

a) There is evidence of mismanagement in the Nigerian public sector.

b) There is evidence of corruption among Nigerian leaders.

c) There is evidence that corruption influences governance failures in Nigeria.

\section{LITERATURE REVIEW}

Corruption which may be defined as the abuse of power for private gains has become the most challenging obstacle to sustainable development and a major cause of governance failures around the world. According to Campos and Pradham (2007) corruption has long plagued organized societies.

From ancient China to modern Europe and North America, governments and societies have struggled to contain corruption. According to them, thousands of years of literature document the presence of corruption in society. They posit that corruption involving individuals, groups or firms, both in the public and private sectors influence the formulation of laws, regulations, decrees and other government policies to the advantage of the people or groups, who exercise political power which in the final analysis lead to governance failures (CAMPOS; BHARGAVA, 2007).

According to Nna, et al (2010) though corruption is not akin to Nigeria, corruption has almost become peculiar to the country so much so that one can hypothesize that Nigeria is perhaps the most corrupt country on earth in the last decade. Adewole, et at (2011) posits that corruption is as old as the Nigerian nation itself, dating back to 1950 s.

According to them, in recent time, the situation has become so bad that corruption has almost turned out to be a national culture. They insist that as of now, the Nigerian society is characterized by social malaise such as insecurity of life, poverty, armed robbery, electoral rigging, moral degeneration, succession crisis, and a general lack of accountability by those entrusted with governance.

According to Adebimpe (2011) corruption is antithetical to justice and development, investment, economic growth and government expenditure. He 
INDEPENDENT JOURNAL OF MANAGEMENT \& PRODUCTION (IJM\&P)

http://www.ijmp.jor.br

v. 9, n. 1, January - March 2018

ISSN: 2236-269X

DOI: 10.14807/ijmp.v9i1.547

believes that corruption destroys the legitimacy of government and insists that corruption was responsible for the first 1966 coup, as well as the overthrow of the Shagari administration in 1983. According to him, corruption undermines competitive efficiency and increases the level of absolute poverty in a country, with the corresponding inflation and hunger (OKERE; SALAU, 2016; HERBERT, 2014; ESSEN, 2016).

\subsection{1 Corruption and Bad Government}

Corruption manifests in many forms including bad government and its failure. Bad governance results to poverty, insecurity, infrastructural decay, despondency, poor social amenities, among others. Girishanker, et al, (2002) believe that governance refers to the exercise of power through a country's economic, social and political institutions that shape the incentives of public policy makers who are the providers of public services.

But today in Nigeria, corruption has resulted in the inability of government to provide services for the citizens as it should, as shown by not being able to pay workers' salaries regularly, inability to provide enough classrooms for children of school age, as well as inability to provide an acceptable level of healthcare, among others. Corruption is also responsible for the inability of government to enforce its own laws, rules and regulations.

The anti-corruption agencies like Economic and Financial Crimes Commission (EFCC) is equally riddled with corruption, therefore, making it very difficult, if not impossible, for government to beat corruption (FOLASADE-KOYI, et al, 2015). Corruption has finally led Nigeria into being branded as a place of plutocrats. According to Ego-Alowes (2015) a plutocrat is someone who trades in and or arbitrages political privileges, rights and concessions.

He insists that because of the ignorance of the dangers of plutocratization by Nigerians, plutocratization alone will ensure that Nigeria never develops or is developable. This is never far from the reality, because since the 1950s through 2016, Nigeria remains an underdeveloped country, despite the times of the oil boom, and this time of the oil doom.

Plutocratization given birth to by corruption has produced many governments since 1960, and at each martial music it has always been mismanagement, 
INDEPENDENT JOURNAL OF MANAGEMENT \& PRODUCTION (IJM\&P)

http://www.ijmp.jor.br

v. 9, n. 1, January - March 2018

ISSN: 2236-269X

DOI: 10.14807/ijmp.v9i1.547

corruption, and the government overthrown or voted out. To this extent, Ego-Alowes (2015) insists that Nigeria is a proof of the believe that every state is as corrupt as her plutocrats are rich (ODITTEH, 2016; TSA, 2016; ONABULE, 2016; BAYAGBOM, 2015).

Even the civilian government that succeeded the military in 1999, despite its desperation against corruption could not leave a legacy of transparency in governance. For example, Marshall (2006) states: President Olusegun Obasanjo has expressed a strong personal commitment to tackling systemic corruption in Nigeria, and the first bill that was passed into law after he was elected into office was The Corrupt Practices and Other Related offences Act.

Unfortunately, the problem of corruption in Nigeria is still present, and there has not been one high-level conviction during Obasanjo's term as president. Also, the privatization and commercialization of Public Enterprises (PEs) has become a subject of probe. Most Nigerians believe that PEs such as the Nigerian Telecommunications Limited, Power Holding Company of Nigeria, among others were given away at ridiculously low prices and shrouded in corruption (OLUWASEGUN; ANOFI, 2015).

According to Nwankwo(2011) top government officials have been otherwise accused of involvement in underhand deals in the exercise. To this extent the Nigerian Labour Congress (NLC) has charged the Nigerian Senate to summon the political will to ensure that all the issues of corruption in the privatization and commercialization probe are pursued to logical end and ensure that those indicted are brought to book.

Bringing corrupt people to book in Nigeria is difficult because the police and other law enforcement agencies are also corrupt. For example, according to Kunav (2005) Nigeria is a well-known corrupt nation and its police force is specifically corrupt with a good amount of confidence.

He believes that those who already think that high profile corrupt cases like that of the dismissed Inspector-General of Police, Mr. Balogun are scandalous should sit up as they would hear and read more of such issues in the police force. These support the views of Smith (2005a) that Sir James Robertson had gerrymandered, cheated, perverted and, by his machinations, perpetrated one of the 
INDEPENDENT JOURNAL OF MANAGEMENT \& PRODUCTION (IJM\&P)

http://www.ijmp.jor.br

v. 9, n. 1, January - March 2018

ISSN: 2236-269X

DOI: 10.14807/ijmp.v9i1.547

most ghastly acts of infamy in British colonial history. The British legacy of corruption in Nigeria is what the government and the people of Nigeria are still struggling to change (UNIAMIKOGBO, 2007, OKONJO-IWEALA, 2015, NWAORGU, 2014).

\subsection{Corruption and Poverty}

Corruption contributes to governance failures and increases poverty in society. Problems of poverty and governance are linked. According to Klugman (2002) if political power is abused, or expressed in weak or improper ways, those with the least power-the poor-are the most likely to suffer.

Weak governance characterized by corruption compromises the efficient delivery of services and benefits to those who need them most; the influence of powerful interest groups biases policies, programmes, and spending away from the poor, and lack of property rights, security and inability to access legal services put the poor at disadvantage, and inhibit them from being in full-control of their lives.

In the circumstances, poor governance generates and reinforces poverty and subverts efforts to reduce it. Combating corruption and strengthening governance are essential preconditions to enhancing the living standards of the poor. He posits that the capacity of government to manage resources efficiently, and to formulate, implement and enforce sound policies and regulations, and respect for institutions that govern economic and social interactions are the basis of good public sector management and crucial for poverty reduction management.

And according to Onalo (2016) almost 95 percent of Nigerian graduates are not employable, because of weak university system, arising from poor government regulations of the universities and corruption. Besides the rising levels of poverty, the rate of unemployment is on the rise, with 60 percent of the 64 percent youth population unemployed (EHIKIOYA, 2015; TAIWO-OBALONYE, 2016).

Corruption is everywhere in Nigeria and it flows freely from the presidential villa, through the 36 state government houses, the federal capital territory, and all 774 local government headquarters. Seriously, today, there are many corruption cases pending before the courts or tribunals involving serving and past state governors and Sunday others.

Recovery of stolen money cannot be a matter of politics, but treated clearly as a matter of criminality. Committing murder, acts of genocide, stealing the resources 
of the nation are not covered by section 308 of the Constitution of the Federal Republic of Nigeria (FAWEHINMI, 2005) Court orders like the one called perpetual injunction, may well stall anti-corruption management in Nigeria if not properly interpreted by the courts and legal luminaries, especially when criminal issues are involved.

Mobilizing about N21billion from Nigeria's treasury for electioneering campaign in 2015, when civil servants were owed huge salary arrears, and the economy in coma, was nothing but corruption (HARDBALL, 2015). For effective anticorruption management and sustainable development agenda, it is imperative to recover such money from the people hiding it either in bushes, farms, holes, rooftops, tank farms, bathrooms, casinos, hotels, fish ponds, petrol service stations, shopping malls and so on.

Nwodo (2015) believes that the last government was corrupt. According to him; revelations at the arms purchase probe have shown the impunity in the last PDP administration. He feels that somebody should fight corruption and bring sanity to government expenditure, and that Nigerians are getting it from this government. He believes that no Nigerian should go to bed hungry and that this country has enough resources to feed and provide the enabling environment to achieve its desires.

But when public resources are plundered as have been done by previous administrations, you can see that the waste in governance has made it impossible for Nigeria to reach its potential. For example, according to Dasuki (2015): That I am aware in November (I cannot remember the exact date), my office requested the CBN to exchange N10billion from the account of the Office of National Security Adviser domiciled in CBN.

The money was exchanged at US\$47m and some Euros which I cannot remember. The exact amount was delivered at my residence. The money was for delegates that attended the nomination convention for the PDP Presidential Nomination. The money was paid and sent to Hon. W. Dudafa, SSAP, Household, and ADC (C-I-C) for distribution on the instruction of the President. Many of the cash payments were just looted. Many people in the ruling party got huge sums of money. 
INDEPENDENT JOURNAL OF MANAGEMENT \& PRODUCTION (IJM\&P)

http://www.ijmp.jor.br

v. 9, n. 1, January - March 2018

ISSN: 2236-269X

DOI: 10.14807/ijmp.v9i1.547

In this corruption episode involving Dasuki (2015) it was revealed that many of the contracts were fake, many of the payments related to the 2015 presidential elections and not for national security. According to Olanipekun (2005) to effectively check corruption, the President needs to check the imperialism in governance at every level. Corruption has single handedly led to the death of countess number of projects in Nigerian.

According to Ayodeji (2005) it is not as if corruption originated in Nigeria, or that she is the only country where corruption is pervasive, but it is worse here because it has been institutionalized. While Emir Sanusi believes that stealing is corruption, the former President Jonathan is of the view that stealing is not corruption; rather he symbolizes the common wealth of all Nigerians as yam and the looters, as goat.

This yam and goat mentality of a matter as serious as embezzlement of public funds gave impetus for huge corruption in the immediate past government in Nigeria. The watchdog agencies, including the media are messed up by Mr. Corruption in Nigeria. The outrageous corruption issues involving the National Security Adviser (NSA), and some media owners have demonstrated the weakness of the watchdog.

According to Macaulay (2015) when the media betrays its essence by taking sides with unprogressive structures of power, it defeats the purpose of having a watchdog in the society. He states that the allegations against some of the media chiefs show not only the corruption influence of power but also the powerful influence of corruption.

\subsection{Corruption and Private Sector Failure}

According to Adewole, et al (2011) the Organized Private Sector (OPS) in Nigeria had been infested by corruption from the 1950s when panels of inquiry were set up to look into the operations of African Continental Bank (ACB) and National Bank of Nigeria (NBN). Corruption in the Nigerian banking sector became worrisome between 1954 and 1960 with allegations of questionable use of public funds by the Eastern and Western regional governments to finance the activities of ACB and NBN.

In this regard, public probes were constituted to verify the allegations. The Foster Sutton Tribunal (1962) found that the manner of injecting public funds into 
ACB was shrouded in mystery. Also, the Coker Commission (1962) found that the financial affairs of NBN did not present a very happy picture because the various loans linked to the Action Group were not secured in any shape or form (UGOANI, 2013).

Corruption returned with full force in the 1990s into the Nigerian banking system leading to the distress and liquidation of many banks from 1993 through 2011. The matter of corruption in the banking sector reached the level that the Central Bank of Nigeria had to inject about N678bn into the banking system to protect deposits interests (THE GUARDIAN, 2011).

The Asset Management Company of Nigeria (AMCON) established by the government to purchase the nonperforming loans of the sick banks was also accused of corruption. According to Yesufu and Itua (2015) AMCON was accused of irregularly accumulating debts amounting to N5trillion, in excess of its N800billion debt ceiling.

Corruption in the banking sector has even been pushed to a higher level by the use of banks as conduit for money laundering activities by public officers. According to Daniel (2016) the EFCC is worried about the activities of banks in money laundering, pointing out that what bankers call private banking has provided a favourable window for top politicians to launder huge sums of public funds.

From this angle, the financial system which is the oil of any economy is also weakened by corruption, and this again provides an easy landing for governance failures, because some governors or presidents that were impeached, convicted or even dead, were also involved in money laundering through the banking system (ADINUBA, 2016, OKWE, 2013, OSEHOBO, 2012).

\section{METHODOLOGY}

\subsection{Research Design}

The exploratory research design was employed for the study. The method is concerned with process rather than consequences, with organic wholeness rather than independent variables, and with meanings rather than behavioural statistics (OSUALA, 2007). This method is evolutionary and historical in nature and it rarely involves the employment of large samples or use of structured questionnaire (ASIKA, 2004, MILES; HUBERMAN, 1994). 


\subsection{Sources of Data}

Data were collected through observations, interviews, books, newspapers, journals, periodicals, government publications among others.

\subsection{Method of Data Analysis}

Data were analyzed through descriptive statistics, and result presented in tables.

\section{PRESENTATION OF RESULT.}

Table 1 was used to answer research question number one, as it provided reliable evidence of mismanagement in the Nigerian public sector by public servants. According to Semenitari (2005b) President Obasanjo was personally worried about mismanagement in public life that he declared: "As you all know, we have put in place a holistic economic reform agenda covering accelerated privatization, public and civil service reforms, and a war against corruption. He admitted that, our current political arrangement has some identical distortions, defects and limitations that call for urgent, focused and realistic attention, hence this initiative on political reforms".

Table 1: Selected Pending Mismanagement/Corruption Cases In Nigeria.

\begin{tabular}{|c|c|c|c|c|}
\hline $\mathrm{S} / \mathrm{N}$ & \multicolumn{2}{|c|}{ Amount } & Brief details & \multirow{3}{*}{$\begin{array}{l}\text { Status } \\
\text { Pending }\end{array}$} \\
\hline \multirow[b]{2}{*}{1} & $\mathrm{~N}$ & $\$$ & Money laundering/bribery / & \\
\hline & & $180 \mathrm{~m}$ & $\begin{array}{l}\text { corruption involving top govt } \\
\text { officers/Halliburton. }\end{array}$ & \\
\hline 2 & & $7.5 b n$ & $\begin{array}{l}\text { Tax evasion by major oil } \\
\text { companies (MOCs) }\end{array}$ & Pending \\
\hline 3 & $\begin{array}{l}2.58 t r \\
\text { illion }\end{array}$ & & Mega oil subsidy scam & Pending \\
\hline 4 & & $24.1 \mathrm{~m}$ & SAGEM SA, ID card scandal & Pending \\
\hline 5 & 5 trn & & $\begin{array}{l}8000 \text { abandoned FG projects } \\
\text { as at } 2014\end{array}$ & Abandoned projects \\
\hline 6 & & $69 \mathrm{bn}$ & $\begin{array}{l}\text { Missing money from } \\
\text { treasury }\end{array}$ & Pending \\
\hline 7 & 15 trn & & $\begin{array}{l}\text { Abandoned projects due to } \\
\text { corruption as at } 2016\end{array}$ & Abandoned projects \\
\hline 8 & & $11 \mathrm{bn}$ & $\begin{array}{l}\text { Unremitted funds to FG by } \\
\text { MOCs }\end{array}$ & Pending \\
\hline 9 & $\begin{array}{l}61.4 \mathrm{~b} \\
\mathrm{n}\end{array}$ & & $\begin{array}{l}\text { Diversion of funds to NSA by } \\
\text { Okonjo-Iweala }\end{array}$ & $\begin{array}{lrr}\text { Cash } & \text { looted by } \\
\text { public } & \text { servants, } \\
\text { others. } & \\
\end{array}$ \\
\hline 10 & & $4 \mathrm{bn}$ & The Abacha case & Recovery in progress \\
\hline 11 & $3.7 \mathrm{bn}$ & & $\begin{array}{l}\text { Cash diverted for personal } \\
\text { use by Badeh }\end{array}$ & Pending \\
\hline
\end{tabular}


INDEPENDENT JOURNAL OF MANAGEMENT \& PRODUCTION (IJM\&P)

http://www.ijmp.jor.br

v. 9, n. 1, January - March 2018

ISSN: 2236-269X

DOI: 10.14807/ijmp.v9i1.547

Table 2 provided the answer for research question number 2, with critical evidence that Nigerian leaders at the highest level of governance have been involved in corruption.

Table 2: Recovery From The Abacha Looted Funds

\begin{tabular}{|l|l|l|l|l|}
\hline S/N & $\begin{array}{l}\text { Year } \\
\text { Recovered }\end{array}$ & $\begin{array}{l}\text { Year } \\
\text { Expected }\end{array}$ & Sources & Amount (\$) \\
\hline 1 & 2014 & & Liechtenstein & $226.4 \mathrm{~m}$ \\
\hline 2 & & & Luxembourg & $321 \mathrm{~m}$ \\
\hline 3 & & Jersey, UK & $313 \mathrm{~m}$ \\
\hline 4 & \multicolumn{3}{|c|}{ Source: Author Fieldwork (2016) } \\
\hline \multicolumn{4}{|c|}{ USA } \\
\hline
\end{tabular}

The reform programmes in table 3 did not achieve the objectives for which they were established. Rather, according to Tunji (2016) they were ostensibly put in place to steal money from government treasury by corrupt public officers; in which case, they were merely used and dumped. This is a credible evidence of mismanagement and corruption in the public sector of the economy.

Table 3: 5 Selected Failed Reform Programmes (1986-2000) in Nigeria

\begin{tabular}{|c|c|c|c|c|c|}
\hline $\mathrm{S} / \mathrm{N}$ & Year & Description & Objectives & Status & $\begin{array}{l}\text { Public } \\
\text { perception of } \\
\text { failure }\end{array}$ \\
\hline 1 & 1986 & $\begin{array}{l}\text { Directorate of } \\
\text { Food, Roads, and } \\
\text { Rural } \\
\text { Infrastructure } \\
\text { (DFRRI) }\end{array}$ & $\begin{array}{l}\text { To help in } \\
\text { poverty } \\
\text { alleviation }\end{array}$ & Failed & $\begin{array}{l}\text { Corrupt, conduit } \\
\text { for siphoning } \\
\text { public funds }\end{array}$ \\
\hline 2 & 1986 & $\begin{array}{l}\text { Mass Mobilization } \\
\text { for Social Justice } \\
\text { Self-Reliance and } \\
\text { Economic } \\
\text { Recovering } \\
\text { (MAMSER) }\end{array}$ & $\begin{array}{l}\text { To accelerate } \\
\text { reduction of } \\
\text { mass illiteracy } \\
\text { in Nigeria }\end{array}$ & Failed & $\begin{array}{l}\text { Corrupt, conduit } \\
\text { for siphoning } \\
\text { public funds into } \\
\text { private pockets }\end{array}$ \\
\hline 3 & 1986 & $\begin{array}{l}\text { National Electoral } \\
\text { Commission } \\
\text { (NEC) }\end{array}$ & $\begin{array}{l}\text { To formulate } \\
\text { new electoral } \\
\text { process and } \\
\text { give new } \\
\text { breed } \\
\begin{array}{l}\text { politicians a } \\
\text { chance }\end{array}\end{array}$ & Failed & $\begin{array}{l}\text { Corrupt, could } \\
\text { not conduct a } \\
\text { credible election }\end{array}$ \\
\hline 4 & 1986 & $\begin{array}{l}\text { Centre } \\
\text { Democratic } \\
\text { Studies (CDS) }\end{array}$ & $\begin{array}{l}\text { To impart } \\
\text { democratic } \\
\text { ideas in the } \\
\text { leaders after } \\
\text { many years of } \\
\text { military rule }\end{array}$ & Failed & $\begin{array}{l}\text { No } \\
\text { consequence }\end{array}$ \\
\hline 5 & 1990 & $\begin{array}{l}\text { Peoples Bank of } \\
\text { Nigeria (PBN) }\end{array}$ & $\begin{array}{l}\text { To ease } \\
\text { access to } \\
\text { credit for the } \\
\text { rural and } \\
\text { urban poor }\end{array}$ & Failed & $\begin{array}{l}\text { Corrupt, } \\
\text { hijacked } \\
\text { powerful } \\
\text { politicians. }\end{array}$ \\
\hline
\end{tabular}

Source: Author Fieldwork (2016) 
Table 4 showed that the level of poverty remains high in Nigeria, despite numerous poverty alleviation programmes. Corruption is responsible for the failure of propoor programmes and has made the majority to wallow in hunger. For example, according to Kale (2012), as at 2010, there was about 38.6 percent of food poverty in North-Central Nigeria, 51.5 percent in North-East, 51.8 percent in North-West, 41.0 percent in South-East. 35.5 percent in South-South and 25.4 percent in South-West. This states the reality that successive governments since 1960 found it almost impossible to feed the citizens, while billions of dollars are shared by corrupt individuals.

Table 4: Nigeria's Poverty Levels (2004 - 2011)

\begin{tabular}{|l|l|l|l|}
\hline Poverty Measure (in \%) & 2004 & 2010 & 2011 \\
\hline Relative poverty (in \%) & 54.4 & 69 & 71.5 \\
\hline Absolute poverty (in \%) & 54.7 & 60.9 & 61.9 \\
\hline Dollar per day (in \%) & 62.8 & 61.2 & 62.8 \\
\hline
\end{tabular}

Source: Fieldwork (2016) Adapted Okafor (2014)

Table 5 explained research question number three, with substantial credible evidence that corruption influences governance failures in Nigeria. From this perspective, it becomes more understandable, why about 70 percent of past administrations are today perceived as corrupt. This may also explain why about 70 percent of Nigerians live in poverty (Ugbabe, 2012, Amaize, 2016, Okafor, 2014).

Table 5: Government Changes in Nigeria 1960-2015

\begin{tabular}{|c|c|c|c|c|c|c|c|c|}
\hline \multirow{2}{*}{$\begin{array}{l}\mathrm{S} / \\
\mathrm{N}\end{array}$} & \multirow{2}{*}{$\begin{array}{l}\text { Year } \\
\text { of } \\
\text { chan } \\
\text { ge }\end{array}$} & \multirow{2}{*}{$\begin{array}{l}\text { Change } \\
\text { agent }\end{array}$} & \multirow{2}{*}{$\begin{array}{l}\text { Head of } \\
\text { government } \\
\text { on change } \\
\text { date } \\
\end{array}$} & \multirow{2}{*}{$\begin{array}{l}\text { Mode of } \\
\text { change }\end{array}$} & \multirow{2}{*}{$\begin{array}{l}\text { Reason of } \\
\text { change }\end{array}$} & \multirow{2}{*}{$\begin{array}{l}\text { Condition of } \\
\text { head of govt } \\
\text { after change }\end{array}$} & \multicolumn{2}{|c|}{ Legacy/popular opinion } \\
\hline & & & & & & & Positive & Negative \\
\hline 1 & 1960 & $\begin{array}{l}\text { Independe } \\
\text { nce }\end{array}$ & $\begin{array}{l}\text { Sir James } \\
\text { Robertson }\end{array}$ & Handover & Independence & $\begin{array}{l}\text { Returned to } \\
\text { UK }\end{array}$ & $\begin{array}{l}\text { Independe } \\
\text { nce }\end{array}$ & $\begin{array}{l}\text { Corruption, } \\
\text { North-South } \\
\text { Dichotomy, } \\
\text { dual } \\
\text { mandate }\end{array}$ \\
\hline 2 & $1966^{a}$ & $\begin{array}{l}\text { Major P.C } \\
\text { Nzeogwu }\end{array}$ & $\begin{array}{l}\text { Sir } \\
\text { AbubakarTa } \\
\text { fawa Balewa }\end{array}$ & $\begin{array}{l}\text { General } \\
\text { elections }\end{array}$ & $\begin{array}{l}\text { Independence } \\
\text { from British }\end{array}$ & Assassinated & $\begin{array}{l}\text { Nationalis } \\
\mathrm{m}\end{array}$ & $\begin{array}{l}\text { Corruption/ } \\
\text { Regionalism } \\
\text {, tribalism }\end{array}$ \\
\hline 3 & $1966^{b}$ & Military & $\begin{array}{l}\text { Gen. J.T.U } \\
\text { Aguiyi-Ironsi }\end{array}$ & $\begin{array}{l}\text { Military } \\
\text { coup }\end{array}$ & Unitary govt & Assassinated & $\begin{array}{l}\text { Campaign } \\
\text { for one } \\
\text { Nigeria }\end{array}$ & $\begin{array}{l}\text { Unitary govt } \\
\text { Decree No } \\
34\end{array}$ \\
\hline 4 & 1975 & $\begin{array}{l}\text { Gen. M } \\
\text { Mohamme } \\
\text { d }\end{array}$ & $\begin{array}{l}\text { Gen. } \\
\text { Yakubu } \\
\text { Gowon }\end{array}$ & $\begin{array}{l}\text { Military } \\
\text { coup }\end{array}$ & Bad govt & Deposed & $\begin{array}{l}\text { One } \\
\text { Nigeria } \\
\text { Creation } \\
\text { of States } \\
\text { Indigeniza } \\
\text { tion policy }\end{array}$ & $\begin{array}{l}\text { Corruption } \\
\text { Brutal Civil } \\
\text { war } \\
\text { Reluctant to } \\
\text { hand over } \\
\text { power, } \\
\text { economic } \\
\text { mismanage }\end{array}$ \\
\hline
\end{tabular}


INDEPENDENT JOURNAL OF MANAGEMENT \& PRODUCTION (IJM\&P)

http://www.ijmp.jor.br

v. 9, n. 1, January - March 2018

ISSN: 2236-269X

DOI: 10.14807/ijmp.v9i1.547

\begin{tabular}{|c|c|c|c|c|c|c|c|c|}
\hline & & & & & & & & ment \\
\hline 5 & 1976 & $\begin{array}{l}\text { Col. B. S } \\
\text { Dimka }\end{array}$ & $\begin{array}{l}\text { Gen. M } \\
\text { Mohammed }\end{array}$ & $\begin{array}{l}\text { Military } \\
\text { coup }\end{array}$ & $\begin{array}{l}\text { Accusations of } \\
\text { marginalizatio } \\
n\end{array}$ & Assassinated & $\begin{array}{l}\text { Creation } \\
\text { of States, } \\
\text { commitme } \\
\text { nt to } \\
\text { handover } \\
\text { by } 1979\end{array}$ & $\begin{array}{ll}\text { The } & \text { Big } \\
\text { Purge } & \end{array}$ \\
\hline 6 & 1979 & Electorate & $\begin{array}{l}\text { Gen } \\
\text { Olusegun } \\
\text { Obasanjo }\end{array}$ & $\begin{array}{l}\text { General } \\
\text { elections }\end{array}$ & $\begin{array}{l}\text { Military } \\
\text { disengagemen } \\
\mathrm{t}\end{array}$ & $\begin{array}{l}\text { Self- } \\
\text { retirement } \\
\text { from Army }\end{array}$ & $\begin{array}{l}\text { Surrender } \\
\text { of Power } \\
\text { to } \\
\text { civilians, } \\
\text { UPE, } \\
\text { OFN, } \\
\text { Indigeniza } \\
\text { tion }\end{array}$ & $\begin{array}{l}\text { Corruption, } \\
\text { FESTAC, } \\
\$ 2.8 \mathrm{~b} \\
\text { allegation }\end{array}$ \\
\hline 7 & 1983 & $\begin{array}{l}\text { Gen. Sani } \\
\text { Abacha }\end{array}$ & $\begin{array}{l}\text { Alhaji Shehu } \\
\text { Shagari }\end{array}$ & $\begin{array}{l}\text { Military } \\
\text { coup }\end{array}$ & $\begin{array}{l}\text { Corruption in } \\
\text { govt. }\end{array}$ & Deposed & $\begin{array}{l}\text { New } \\
\text { Universitie } \\
\text { S, Green } \\
\text { Revolution }\end{array}$ & $\begin{array}{l}\text { Corruption } \\
\text { No direction, } \\
\text { over politics }\end{array}$ \\
\hline 8 & 1985 & $\begin{array}{l}\text { Gen. Sani } \\
\text { Abacha }\end{array}$ & $\begin{array}{l}\text { Gen. } \\
\text { Mummadu } \\
\text { Buhari }\end{array}$ & $\begin{array}{l}\text { Military } \\
\text { coup }\end{array}$ & $\begin{array}{l}\text { Draconian } \\
\text { rulership }\end{array}$ & Deposed & $\begin{array}{l}\text { War } \\
\text { against } \\
\text { Indisciplin } \\
\text { e }\end{array}$ & $\begin{array}{l}\text { Trade } \quad \text { by } \\
\text { barter, } \\
\text { Decree No. } \\
2\end{array}$ \\
\hline 9 & 1993 & Military & $\begin{array}{l}\text { Gen Ibrahim } \\
\text { B. } \\
\text { Babangida }\end{array}$ & Military & $\begin{array}{l}\text { Withdrawal } \\
\text { from politics by } \\
\text { military }\end{array}$ & $\begin{array}{l}\text { Stepped } \\
\text { aside }\end{array}$ & $\begin{array}{l}\text { Creation } \\
\text { of States, } \\
\text { Poverty } \\
\text { Reduction } \\
\text { Programm } \\
\text { es }\end{array}$ & $\begin{array}{l}\text { SAP, } \\
\text { Corruption } \\
\text { June } 12 \\
\text { election } \\
\text { cancellation }\end{array}$ \\
\hline 10 & 1993 & Military & $\begin{array}{l}\text { Chief } \\
\text { Earnest } \\
\text { Shonekan }\end{array}$ & Military & $\begin{array}{l}\text { Unstable. No } \\
\text { direction }\end{array}$ & Deposed & None & No direction \\
\hline 11 & 1998 & Military & $\begin{array}{l}\text { Gen. Sani } \\
\text { Abacha }\end{array}$ & Military & $\begin{array}{l}\text { Death of } \\
\text { Abacha }\end{array}$ & Died in power & $\begin{array}{l}\text { Creation } \\
\text { of States, } \\
\text { PTF, } \\
\text { FEAP }\end{array}$ & $\begin{array}{l}\text { Corruption, } \\
\text { one Million } \\
\text { Man Match, } \\
\text { human right } \\
\text { abuse, self } \\
\text { succession } \\
\text { plan }\end{array}$ \\
\hline 12 & 1999 & Electorate & $\begin{array}{l}\text { Gen. A. } \\
\text { Abubakar }\end{array}$ & $\begin{array}{l}\text { Surrender } \\
\text { of power }\end{array}$ & $\begin{array}{l}\text { Election } \\
\text { victory }\end{array}$ & $\begin{array}{l}\text { Retired from } \\
\text { the Army }\end{array}$ & $\begin{array}{l}\text { Release } \\
\text { of Political } \\
\text { Prisoners, } \\
\text { Surrender } \\
\text { of Power }\end{array}$ & $\begin{array}{l}\text { Minimum } \\
\text { wage } \\
\text { confusion, } \\
\text { Huge } \\
\text { depletion of } \\
\text { foreign } \\
\text { reserves }\end{array}$ \\
\hline 13 & 2003 & Electorate & $\begin{array}{l}\text { Chief O. } \\
\text { Obasanjo }\end{array}$ & Sworn in & $\begin{array}{l}\text { Election } \\
\text { victory }\end{array}$ & $\begin{array}{l}\text { Sworn in for } \\
2^{\text {nd }} \text { tenure }\end{array}$ & $\begin{array}{l}\text { Debt } \\
\text { relief, } \\
\text { Reforms, } \\
\text { Poverty } \\
\text { alleviation, } \\
\text { Anticorrup } \\
\text { tion } \\
\text { stance. }\end{array}$ & $\begin{array}{l}\text { Corruption } \\
3^{\text {rd } \quad \text { term }} \\
\text { politics, } \\
\text { distortions }\end{array}$ \\
\hline 14 & 2007 & Electorate & $\begin{array}{l}\text { Chief O. } \\
\text { Obasanjo }\end{array}$ & $\begin{array}{l}\text { Handed } \\
\text { over to } \\
\text { Yar' Adua }\end{array}$ & $\begin{array}{l}\text { Election } \\
\text { victory }\end{array}$ & $\begin{array}{l}\text { Retired to } \\
\text { Ota farms / } \\
\text { politics }\end{array}$ & $\begin{array}{l}\text { Debt } \\
\text { relief, } \\
\text { Reforms, } \\
\text { Poverty }\end{array}$ & $\begin{array}{l}\text { Corruption } \\
3^{\text {rd }} \text { term } \\
\text { politics } \\
\text { distortions, }\end{array}$ \\
\hline
\end{tabular}


INDEPENDENT JOURNAL OF MANAGEMENT \& PRODUCTION (IJM\&P)

http://www.ijmp.jor.br

v. 9, n. 1, January - March 2018

ISSN: 2236-269X

DOI: 10.14807/ijmp.v9i1.547

\begin{tabular}{|c|c|c|c|c|c|c|c|c|}
\hline & & & & & & & $\begin{array}{l}\text { alleviation, } \\
\text { Anticorrup } \\
\text { tion } \\
\text { stance. }\end{array}$ & \\
\hline 15 & 2010 & $\begin{array}{l}\text { National } \\
\text { Assembly }\end{array}$ & $\begin{array}{l}\text { Alhaji } \\
\text { Umaru } \\
\text { Yar'Adua }\end{array}$ & $\begin{array}{l}\text { Doctrine } \\
\text { of } \\
\text { necessity }\end{array}$ & $\begin{array}{ll}\text { Death } & \text { of } \\
\text { Yar'Adua }\end{array}$ & Died in power & $\begin{array}{l}\text { Governme } \\
\mathrm{nt} \text { of } \\
\text { national } \\
\text { unity. } \\
\text { Equity }\end{array}$ & $\begin{array}{l}\text { Leniency } \\
\text { with criminal } \\
\text { militancy, no } \\
\text { control over } \\
\text { official } \\
\text { corruption }\end{array}$ \\
\hline 16 & 2011 & Electorate & $\begin{array}{l}\text { Dr. } \\
\text { Goodluck } \\
\text { Jonathan }\end{array}$ & Sworn in & $\begin{array}{l}\text { Election } \\
\text { victory }\end{array}$ & $\begin{array}{l}\text { Sworn in to } \\
\text { complete } 2^{\text {nd }} \\
\text { tenure from } \\
\text { Yar'Adua's } \\
\text { presidency }\end{array}$ & $\begin{array}{l}\text { Approval } \\
\text { of more } \\
\text { universitie } \\
\text { s, Unity in } \\
\text { diversity }\end{array}$ & $\begin{array}{l}\text { Corruption, } \\
\text { tenure } \\
\text { politics }\end{array}$ \\
\hline 17 & 2015 & Electorate & $\begin{array}{l}\text { Dr. } \\
\text { Goodluck } \\
\text { Jonathan }\end{array}$ & $\begin{array}{l}\text { Handed } \\
\text { over to } \\
\text { Buhari }\end{array}$ & $\begin{array}{l}\text { Election } \\
\text { defeat. }\end{array}$ & $\begin{array}{l}\text { Voted out of } \\
\text { power }\end{array}$ & $\begin{array}{l}\text { Approval } \\
\text { of more } \\
\text { universitie } \\
\text { s, Unity in } \\
\text { diversity }\end{array}$ & $\begin{array}{l}\text { Corruption, } \\
\text { tenure } \\
\text { politics, } \\
\text { Boko } \\
\text { Haram, } \\
\text { Chibok Girls' } \\
\text { Seizure }\end{array}$ \\
\hline
\end{tabular}

Source: Author Fieldwork (2016).

Figure 1 showed Sir Robertson and foremost nationalists of Dr. Azikiwe, Chief Awolowo and Sir. Bello in discussions about Nigeria's Independence. No doubt, Sir Robertson, a very brilliant representative of the Queen of Great Britain and Northern Ireland, and as Governor-General of Nigeria, who was very clear about the dual mandate, put the final touch to all matters of Nigeria's Independence 1960

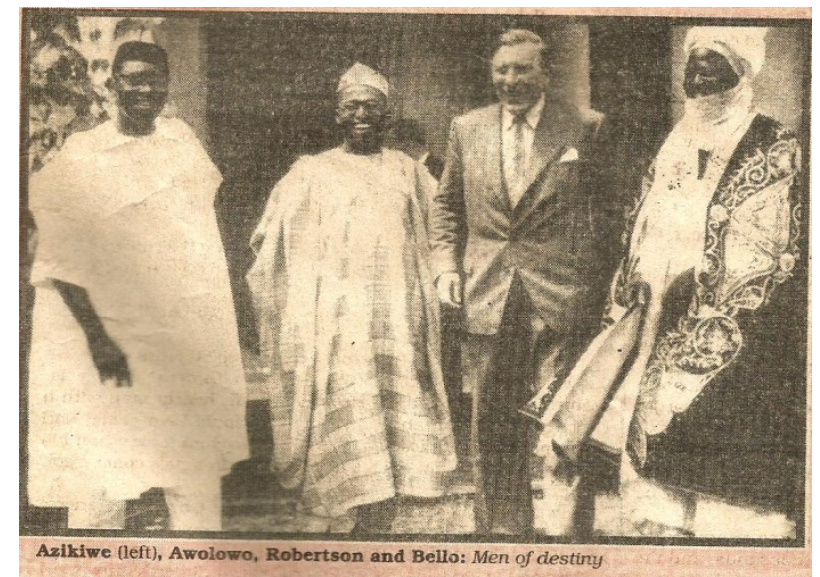

Figure 1: The Nationalists and The Umpire.

Source: Author Fieldwork (2016) Adapted from Tell, March 7, (2005, p. 43).

Table 6 showed only one little case of how public funds were looted at the presidency by public officers and their cronies. According to Alli (2015) "sometimes, there were accompanying documents, most times, there was nothing except account details of contractors". 
These people looted the billions of naira that were allocated for the fight against insurgency, causing many innocent and patriotic soldiers to die needlessly and they are not remorseful. The immediate past government shared N600million to six chairmen of the contact and mobilization committee the 2015 general elections, N300million to an account given by a former party chairman, N200million to a state governorship candidate and N100million to a former PDP governor, so as to win the last general elections (ADEYEMI, 2015).

Government should aim at recovering these monies, because immunity does not apply to criminal investigation, and stealing is not an example of good governance, but a clear case of corruption in governance. According to Fawehinmi (2005) no governor, no deputy governor, no president or vice president is immune from criminal investigation. So, when you plead section 308, do not include criminal investigation. Sharing of public funds as briefly described in table 6 greatly undermines the credibility of governance.

Table 6: Corrupt Sharing of Public Money At The Presidency (2015)

\begin{tabular}{|c|c|c|c|}
\hline \multirow{2}{*}{$\mathrm{S} / \mathrm{N}$} & \multirow{2}{*}{$\begin{array}{l}\text { Name of } \\
\text { Beneficiaries }\end{array}$} & \multicolumn{2}{|l|}{ Amount } \\
\hline & & $\mathrm{N}$ & $\$$ \\
\hline 1 & $\begin{array}{l}\text { Jabbama Ada } \\
\text { Global Ltd }\end{array}$ & $\begin{array}{l}\text { 400millio } \\
\mathrm{n}\end{array}$ & \\
\hline 2 & R. R Hospital & $\begin{array}{l}\text { 750millio } \\
\mathrm{n}\end{array}$ & \\
\hline 3 & Barr. I. M Bala & $\begin{array}{l}\text { 150millio } \\
\mathrm{n}\end{array}$ & \\
\hline 4 & $\begin{array}{l}\text { African Cable } \\
\text { TV }\end{array}$ & $\begin{array}{l}\text { 350millio } \\
\mathrm{n}\end{array}$ & \\
\hline 5 & $\begin{array}{l}\text { Nigerian } \\
\text { Defence } \\
\text { Academy }\end{array}$ & $\begin{array}{l}\text { 159millio } \\
\mathrm{n}\end{array}$ & \\
\hline 6 & B. B & $\begin{array}{l}\text { 350millio } \\
\mathrm{n}\end{array}$ & \\
\hline 7 & Abuja EDC & $\begin{array}{l}\text { 125millio } \\
\mathrm{n}\end{array}$ & \\
\hline 8 & $\begin{array}{l}\text { Coscharis } \\
\text { Motors }\end{array}$ & $\begin{array}{l}\text { 119millio } \\
\mathrm{n}\end{array}$ & \\
\hline 9 & PDP Reps & $\begin{array}{l}\text { 380millio } \\
\mathrm{n}\end{array}$ & \\
\hline 10 & $\begin{array}{ll}\text { Heirs } & \text { BDC } \\
\text { Limited }\end{array}$ & $\begin{array}{l}\text { 751millio } \\
\mathrm{n}\end{array}$ & \\
\hline 11 & $\begin{array}{l}\text { Political } \\
\text { Campaign }\end{array}$ & 1.5billion & \\
\hline 12 & $\begin{array}{l}\text { DAAR } \\
\text { Communicatio } \\
\text { ns }\end{array}$ & $\begin{array}{l}2.120 \text { billi } \\
\text { on }\end{array}$ & \\
\hline 13 & $\begin{array}{l}\text { E-Force Inter- } \\
\text { services Ltd }\end{array}$ & & $\begin{array}{l}\text { 147thous } \\
\text { and }\end{array}$ \\
\hline
\end{tabular}

Source: Author Fieldwork (2016) 


\subsection{Discussion}

The findings of the present study have demonstrated in eloquent terms that Nigeria is riddled with mismanagement, misgovernment, distortions, defects, limitations and corruption. The study also unveiled credible reports that corruption lies at the heart of poverty, abandonment of projects, programmes and ultimately, governance failures in Nigeria.

Table 1 showed a small number of corruption cases involving public servants still not resolved. To attest to high level corruption in Nigeria, table 2 showed few recoveries from funds looted from public treasury, table 3 was used to provide examples of failed reform programmes in Nigeria, while table 4 demonstrated the level of poverty in Nigeria as at 2011.

Table 5 provided critical evidence that corruption more than any other factor, contributed to governance failures in Nigeria. Figure 1 evaluated the reckless manner with which public funds were mismanaged in recent history. The public perception is that some programmes were merely designed to siphon public money into private pockets by corrupt public officials and sundry others.

This perhaps justifies the preoccupation of the present government with the fight against corruption. President Buhari with the active support of $G 7$ leaders is spending a great deal of his time chasing the monumental loot from the Nigerian treasury spanning the years of military rule through the 16 years of civil rule up to 2015.

The task is heavy, because the loot is heavy. The Abacha loot alone had promoted Nigeria to become the 4th most corrupt nation in the world. For two or three years, the nation has been contending with the problem of over two trillion naira oil subsidy fraud of which no public officer admits responsibility or knowledge.

The level of mismanagement and corruption in public life in Nigeria is baffling, taking into account the Abacha groundbreaking fraud, the crazy arms deal, the huge tax evasion by MOCs, the railway rehabilitation fraud, among others. The report of the former finance minister that she approved the diversion of N61.4bn to the NSA without proper authorization and legislative appropriation negates the principles of sound management. 
INDEPENDENT JOURNAL OF MANAGEMENT \& PRODUCTION (IJM\&P)

http://www.ijmp.jor.br

v. 9, n. 1, January - March 2018

ISSN: 2236-269X

DOI: 10.14807/ijmp.v9i1.547

This level of mismanagement no doubt created the room for such funds needed to fight Bokoharam to be easily relooted by politicians, business-people, religious-people, military-people and their wives, boyfriends, girlfriends, in-laws, comrades, touts, agents, governors, militants, ministers, and sundry others in society.

This awful situation would have been avoided if good management was exercised over the funds recovered from the Abacha loot. If the British tried to create a conservative middle class, the successive governments succeeded in eliminating the middle class, and instead created two extreme classes: The plutocrats and the paupers.

This type of situation may be responsible for the subsisting militancy and Bokoharam phenomenon in Nigeria. The plutocrats are enjoying their loot, while the paupers are suffering. For example, the ex-petroleum minister who was in charge of almost 95 percent of the country's revenue is now facing multiple charges of mismanagement and corruption; including the one for an oil deal involving a whopping N9trillion since 2013.

Besides this, she had admitted before the Senate Committee on Finance in another probe that she spent a whopping N3.5billion on kerosene subsidy without appropriation in flagrant violation of the provisions of the 1999 constitution of the Federal Republic of Nigeria. In 2014, the House of Representatives also ordered an investigation of an alleged squandering of billions of Naira from government funds by the former petroleum minister on the maintenance of a private jet.

The probe was instituted based on reliable evidence, and it was estimated that she squandered about N130m monthly to maintain the jet, solely for her personal needs and those of her immediate family. According to Emewu (2015) the ex-petroleum minister was equally involved in a N70m donation to her political party at the time she was accused of $\$ 20 b n$ theft, the sum which Price Water House, Coopers, reported missing from the account of the NNPC, under her watch. This is just a single case of what happens in other MDAs in Nigeria.

Even PEs like NITEL the PHCN, among others, were dispensed with on less than transparent conditions, and in manners shrouded in corruption. The result of this study supports the works of previous researchers like Stapenhurst and Sedigh 
(1999). Adebimpe (2011) Adewole, et al (2011), Nna, et al (2010) among others, that corruption leads to mismanagement, misgovernment, poverty and ultimately undermines the legitimacy of government.

\subsection{Recommendations}

i. Government should at all times ensure to exercise proper control over the activities of its appointees, to avoid the abuse of their official discretion, as is evident today.

ii. The matter of abandoned projects all over the country worth about N15trillion is on the high side. Efforts should focus towards completing them to make life more enjoyable for the people.

iii. Curbing squandermania by public servants needs to be addressed before the country is liquidated. A situation where a public officer flies in a private jet to his or her village meetings, funerals, among others is absurd and unacceptable.

iv. The issues involved in the sale of the national telecommunications giant, NITEL, that is shrouded in corruption lingers on without end. The government should take necessary steps to settle the issues in the most equitable manner.

v. From the benefit of this study, it is no longer in doubt that corruption lies at the heart of governance failures in Nigeria. It is therefore necessary for political leaders to exercise necessary care to avoid the past mistakes, so as to redeem the image of Nigeria and Nigerians from public opprobrium.

vi. The judiciary and legal scholars should work together and make a clear prouncement on whether any Nigerian is immune from criminal investigation in view of section 308 of our Constitution. This will be a sound starting point for the war against corruption in Nigeria.

\subsection{Scope of further study}

Further study should examine the relationship between mismanagement and militancy to see if necessary actions may be taken to check the bad situation in Nigeria. 


\section{CONCLUSION}

It was established through credible reports that Nigeria has been drenched in corruption since the colonial days. This strong root is perhaps responsible for the time it is taking the nation to win the war against corruption. Mismanagement, misgovernment and corruption can be said with a high degree of certainty, to be responsible for frequent change of government, poverty, projects abandonment, as well as the elimination of the middle class in Nigeria.

Discretionary powers breed mismanagement and corruption. Elementary knowledge of management would suggest that public officers such as ministers, must adhere to their discretionary approval limits, or obtain the prior approval of higher authorities for any excesses. But it would appear that government officials categorized recovered looted funds as free funds that could be used with a sense of waste.

The MDAs should be the power house of administrative efficiency in Nigeria, and Nigeria should run on the effectiveness of the MDAs, among others. (OLAOPA, 2015). To this extent there is need for a huge dose of political will, managerial creativity and presidential courage to call the overzealous and corrupt officials to order.

Despite President Obasanjo's personal commitment to fight corruption and his usual sagacious and dexterous comments of: "I dey kampe; I dey laugh; no shaking"; corruption still dey kampe; and corruption still dey laugh, in Nigeria. In Nigeria, people received bribes, and they knew they collected bribes, and they are refunding, yet they go to court to claim innocence of corruption and people are laughing.

The situation where about 70 percent of past administrations are perceived as corrupt makes the whole context laughable. Through critical descriptive analysis, it was found that corruption is highly responsible for governance failures in Nigeria. It was also found that there is corruption among leaders, and that mismanagement dominated governance in Nigeria in the last decades.

This result finds support in the works of Stapenhurst and Sedigh (1999), Adebimpe (2011), Adewole, et al (2011), Nna, et al (2010), and the strong views of Adeyemi (2015) among others that past mismanagement destroyed the economy. This is the objective of the study. 
INDEPENDENT JOURNAL OF MANAGEMENT \& PRODUCTION (IJM\&P)

http://www.ijmp.jor.br

v. 9, n. 1, January - March 2018

ISSN: 2236-269X

DOI: 10.14807/ijmp.v9i1.547

\section{REFERENCES}

ABUBAKAR, M. (2007) The Zoning is undemocratic says Aja-Wachukwu. The Guardian, v. 25, n. 10566, p. 8.

ADEBIMPE, I. A. (2011) Corruption The Bane of Nigeria's Development. International Journal of Social and Policy Issues, v. 8, n. 1, p. 231-240.

ADEWOLE, O. A.; BALOGUN, S.; OLAJIDE, A. O. (2011) Corruption in Nigeria: A New Paradigm for Effective Control. International Journal of Social Issues, v. 8, n. 1, p. 7-16.

ADEYEMI, S. (2015) Past Mismanagement destroyed economy, says government. The Nation, v. 10, n. 3427, p. 5

ADINUBA, C. D (2016) Developmentalism and Governance in Nigeria. Daily Sun, v. 13, n. 3444, p. 14.

AGWUNOBI, J. C. (2005) The Nigerian Military in a Democratic Society. Logicgate Media Ltd. Aba .

AKINREMI, A. (2015) Journalist launches crime control initiative. The Nation, v. 10, n. 3427 , p. 4.

AKINTAYO, I. (2016) Nigeria needs profound anti-corruption framework. The Guardian, v. 33, n. 13752, pp. 47.

ALLI, Y. (2015) Dasuki: I was acting on Jonathan's instructions. The Nation v. 10, n. 3427, p. 1-6.

ALLI, Y. (2012) N400bn Subsidy Scam - Indicted Marketers Push for Plea Bargaining. The Nation, v. 7, n. 2228, p. 6.

AMAIZE, E. (2016) Gov Okowa's Political Father, Oyovbaire opens up. Saturday Vanguard, v. 17, n. 9110, p. 15\&20.

ANUMIHE, I. (2016a) FG Loses Over $\$ 518$ M to oil swap, says NEITI. Daily Sun, v., 13, n. 3451, p. 31.

ANUMIHE, I. $\left(2016^{\text {b }}\right)$ Litigations Stall release of funds recovered from looters. Daily Sun, v. 10, n. 3369, p. 44.

ASIKA, N. (2004) Research Methodology: A Process Approach $1^{\text {st }}$ edition Mukugamu \& Brothers Enterprises, Lagos.

AYODEJI, K. (2015) Corruption bigger than Nigeria? The Nation, v. 10, n. 3427, p. 11.

BAYAGBON, M. (2015) How Okonjo-Iweala diverted N61.4bn Abacha loot to NSAReport. I approved the transfer but gave three conditions - Okonjo-Iweala. Vanguard, v. 25, n. 6264, p. 3.

CAMPOS, J. E.; BHARGAVA, V. (2007) Tackling a Social Pandemic. In: CAMPOS, J. E.; PRADHAM, S. (eds) The Many Faces of Corruption: Tackling Vulnerabilities at the Sector Level. The World Bank, Washington, D. C. p. 25

CAMPOS, J. E.; PRADHAM, S. (2007) The Many Faces of Corruption: Tackling Vulnerabilities at the Sector Level. The World Bank, Washington, D. C. 
CONSTITUTION OF THE FEDERAL REPUBLIC OF NIGERIA (1999), Section, 308, Abuja.

CORRUPT PRACTICES ACT (1925), USA.

DANIEL S. (2016) Money Laundering: We will go after bank MDs Magu, EFCC chair. Saturday Vanguard, v. 17, n. 9110, p. 7.

DASUKI, S. (2015) Dasuki: I was acting on Jonathan's Instructions. I have been publicly indicted and any statement may jeopardize my defence. The Nation, v. 10, n. 3427, p. 126.

EGO-ALOWES, J. (2015) Every country is as corrupt as her plutocrats are rich. Daily Sun, v. 10, n. 3247, p. 53.

EHIKIOYA, A. (2015) Buhari decries 60 percent youths' unemployment: The Nation, v. 10, n. 3427. P. 5.

ELAIGWU, J. I. (1985) The Military in Politics: An Afrocentric Perspective. Paper Commissioned for the Nigerian Air Force Day, 1985, Seminar, at the Nigerian Institute of International Affairs, Lagos, $22^{\text {nd }}$ April, 1985.

EMEWU, I. (2015) London Police nab ex-Petroleum Minister, Diezani-Saturday Sun, v. 12, n. 665, p. 5.

ERIYE, F. (2011) Weep not for Farida: It will take more than one sensational sacking to revive anti-graft war. The Nation on Sunday, v. 6, n. 1956, p. 11.

ERO, A. (2005) Naira in the Holes. Tell Magazine, December 26, 2005, p. 42.

ESSEN C. (2016) Institute hinges abandoned N15trn projects on corruption. The Guardian, v. 32, n. 13691, p. 35.

FAWEHINMI, G. (2005) Alamieyeseigha is a common criminal. Tell December 19, 2005, p. 32.

FOLASADE-KOYI, A.; RAHEEM, T.; ITUA, F. (2015) Lamorde: EFCC boss in soup over N1trillion "looted funds". Daily Sun, v. 10, n. 3247, p. 6.

GIRISHANKAR, N.; HAMMERGREN, L.; HOLMES, M.; KNACK, S.; LEVY, B.; LITVACK, J.; MANNING, N.; MESSICK, R.; RINNE, J.; SUTCH, H. (2002) Governance. In J. KLUGMAN (ed.) A Sourcebook for Poverty Reduction Strategies. Core Techniques and Cross-Cutting Issues, v. 1, p. 269-299, The World Bank, Washington, D. C.

HARDBALL (2015) PDP's Self-damnation. The Nation, v. 10, n. 3427, p. 48.

HERBERT, I. (2016) we'll support Buhari to recover looted funds. Germany assures. Saturday Sun, v. 12, n. 668, p. 42.

KALE, Y. (2012) The Nigeria Poverty Profile 2010 Report. Press Briefing by the Statistician-General of the Federation Chief Executive Offiver, National Bureau of Statistics Held at the Conference Room $5^{\text {th }}$ Floor NBS Headquarters, Central Business District, Abuja on Monday, 13 $3^{\text {th }}$ February 2012.

KERRY, J. (2016) Global cost of Corruption US\$2.6trillion per annum. Nigerian Television Authority, International News August, 23, 2016, Abuja.

KLUGMAN, J. (2002) A Sourcebook for Poverty Reduction Strategies. Core Techniques and Cross-Cutting Issues, v. 1, The World Bank Washington, D. C. 
KPUNDEH, S. J. (1999) The Fight Against Corruption in Sierra Leone. In: STAPENHURST, R.; KPUNDEH, S. J. (eds) Curbing Corruption: Toward a Model for Building National Integrity. The World Bank, Washington D. C p. 207-232.

KUNAV, C. (2005) Nigeria, itself, is super corrupt. Tell Magazine, March 7, pp 17.

LACCINO, L. (2015) Nigeria President Muhammadu Buhari Sets up Anti-corruption Advisory. International Business Times, August 11, 2015 12:16 BST.

MACAULAY, F. (2015) Weakness of the watchdog. The Nation, v. 10, n. 3427, p. 13.

MANUAKA, T. (2005) The fall of the 'Governor General'. Tell Magazine, December 19, 2005. P. 30-31.

MARSHALL, D. (2006) Afterward: In: STAPENHURST, R.; JOHNSTON, N.; PELIZZO, R. (eds). The Role of Parliament in Curbing Corruption. The World Bank, Washington, D. C p. 227-236.

MAZRUI, A. (1975) Soldiers and Kinsmen: The Making of a Military Ethnocracy Beverly Hills, Sage.

MEDIA TRUST LTD (2005) Corruption: The Trouble with Nigeria. Tell Magazine, December 26, 2005 p. 17.

MILES, M. B.; HUBERMAN, A. M. (1994) Qualitative Data Analysis-An Expanded Sourcebook. Sage. Thousand Oaks, California.

NA ABBA, G. U (2006) Corruption is Everywhere - Na Abba. Tell Magazine, v. 7, February 13, 2006, p. 48-52.

NNA, N. J.; IGWE, P. I.; TAYLOR, T. (2010) Corruption and Poverty: The Experience of Nigeria: The Nigerian Journal of Politics and Public Policy, v. 6, n. 1-2, p. 139 $-156$.

NWANKWO, N. (2011) BPE Probe: Time To Defend Our National Heritage. Nigerian Public Opinion, v. 1, n. 5, p. 34.

NWAORGU, O. C. (2014) Inactive Squares and the Rumbling State. Inaugural Lecture Series N. 110, University of Port Harcourt, Port Harcourt, Nigeria.

NWIZU, G. C. (2002) Studies in Modern Public Administration. Okigwe, Marco Press.

NWODO, O. (2015) \$2bn arms probe shows impunity in last PDP government says Nwodo. The Nation, v. 10, n. 3427, p. 43.

NZENWA, S. O. E (2000) Overview of Successive Nigerian Regimes. In: NZENWA, S. O. E. (ed) Micro-Credit and Development. Poverty Alleviation in Nigeria. Lagos Mbeyi \& Associates (Nig) Ltd. P. 64-88

OBASANJO, O. (2016) From Ibadan School: Agenda for good governance. The Guardian, v. 32, n. 13579, p. 20.

ODITTAH, C. (2016) How Nigeria was fleeced in \$1.76bn Lagos - Kano rail Line rehabilitation contract. The Guardian, v. 32, n. 13691, p. 176.

OKAFOR, F. O. (2014) Economic and Financial Inclusion Strategies for Arresting Systemic Poverty Amidst Robust Economic Growth in Nigeria. Paper presented at 
INDEPENDENT JOURNAL OF MANAGEMENT \& PRODUCTION (IJM\&P)

http://www.ijmp.jor.br

v. 9, n. 1, January - March 2018

ISSN: 2236-269X

DOI: 10.14807/ijmp.v9i1.547

the $4^{\text {th }}$ Accounting and Finance Research Association. (AFRA) International Conference at Abakaliki, Nigeria.

OKERE, R.; SALAU, S. (2016) NEITI, EFCC go after oil firms over unremitted \$11billion. The Guardian, v. 32, n. 13695, pp 176.

OKONJO-IWEALA, N. (2015) Correcting Gross Misrepresentation of the Economy. The Guardian, Thursday, May 28, 2015, pp. 58.

OKWE, M. (2013) CBN, NDIC, takeover NERFUND Management. The Guardian, v. 30, n. 12709, p. 6.

OLANIPEKUN, O. (2005) Let's Follow Due Process. Tell Magazin, December 19, p. 34.

OLAOPA, T. (2015) Governance Reform in Nigeria: Imperative of a New National Productivity Paradigm. The Guardian, Thursday May 28, p. 19.

OLOKETUYI, S. (2005) Fall of The Super Cop. Tell Magazine, March 7, 2005, p. 17 OLUWASEGUN, V.; ANOFI, D. (2015) Reps to investigate Nitel, Mtel sale. The Nation, v. 10, n. 3417, p. 11.

OMONIJO, B.; AGANDE, B.; OOTA, A. (2005) Obasanjo Parries Question on $3^{\text {rd }}$ Term Plot. Saturday Vanguard, v. 12, n. 482, p. 7.

ONABULE, D. (2016) Looters' Challenge for President Buhari. Daily Sun, v. 10, n. 3369, p. 45.

ONALO, C. (2016) A resilient economy is one governed by best brains - Prof. Onalo. Saturday Vanguard, v. 17, n. 9110, p. 4.

OSEHOBO, V. (2012) 67 Million Youths Unemployed - Minister. Nigerian Pilot, v. 2, n. 154, p. $1-2$.

OSINBAJO, Y. (2017) Nigeria Can't Grow Without Stopping Corruption. The Nation, v. 11, n. 3854, p.6.

OSUALA, E. C. (2007) Introduction to Research Methodology. $3^{\text {rd }}$ edition. Africana-First Publishers Ltd. Onitsha.

SEMENITARI, I. (2005a) Give the Leadership A Chance - Senator Udo Udoma Tell Magazine, March 7, p. 27.

SEMENITARI, I. $\left(2005^{\text {b }}\right)$ The Presidential Memo. Tell Magazine, March 7, p. 7

SMITH, H. (2005a) The Evils The British Did. By Ayodele Akinkuotu. Tell Magazine, March 7, p. 33.

SMITH, H. (2005 $\left.{ }^{\text {b }}\right)$ My Last Days In Nigeria. Tell Magazine, March 7, 2005, p. 42

SMITH, H. $\left(2005^{c}\right)$ If Nigeria is Unstable, Hold the British. Tell Magazine, March 7 , 2005, p. 34.

STAPENHURST, R.; SEDIGH, S. (1999) An Overview of The Costs of Corruption and Strategies to Deal with It. In: STAPENHURST, R.; KPUNDEH, S. J. (Eds) Curbing Corruption: Toward a Model for Building National Integrity - The World Bank, Washington, D. C. p. 1-9.

SOWEMIMO, A. (2006) The Problems with Nigeria. Tell Magazine, July 31, p. 48. 
TAIWO-OBALONYE, J. (2016) Arms deal: Presidency recovers N7bn, indicts 320 contractors. Daily Sun, v. 10, n. 3269, p. 8

TELL MAGAZINE (March 7, 2005) Cover Stories.

THE GUARDIAN (2011) Editorial. Nationalization of Banks. The Guardian, v. 29, n. 11922, p. 14.

TSA, G. (2016) Armsgate: How Badeh diverted $\$ 3.7 \mathrm{bn}$ for personal use-Witness, Daily Sun, v. 10, n. 3369, p. 7.

TUNJI, B. (2016) Our leaders as rapists. Daily Sun, v. 10, n. 3369, p. 18.

UGBABE, O. R. (2012) Nigeria's Pivotal Moment. A semi-annual Journal on Business and the Economy, v. 2, n. 1, First Bank, p. 6-20.

UGOANI, J. N. N. (2016) Political Will and Anticorruption Crusade Management in Nigeria. Independent Journal of Management \& Production, v. 7, n. 1, p. 72-97.

UGOANI, J. N. N. (2013) Power of Bank Credit on Economic Growth - A Nigerian Perspective. International Journal of Financial Economics, v. 1, n. 3, p. 93-102.

UNIAMIKOGBO, S. O. (2007) Management Imperatives of Economic Reforms. Management in Nigeria, v. 43, n. 1, p. 20-27.

WILLIAMS, D. (1981) Shehu Shagari: My Vision of Nigeria. London. Frank Case \& Co. Ltd. P. ix-xiv

YESUFU, K.; ITUA, F. (2015) House to Probe N5trillion AMCON debt, FCT land swap deal. Daily Sun, v. 10, n. 3247, p. 3. 